\title{
The future plans and dilemmas of Chinese students studying in Hungary: A narrative analysis
}

\author{
XUEYAN LI ${ }^{1}$ and HENRIETT PRIMECZ ${ }^{2 *}$
}

\footnotetext{
${ }^{1}$ Doctoral School of Sociology and Communication Science, Corvinus University of Budapest, Budapest, Hungary

${ }^{2}$ Institute of Management and Organization, Corvinus University of Budapest, Budapest, Hungary
}

Received: February 7, 2021 • Revised manuscript received: June 11, 2021 • Accepted: July 1, 2021

Published online: August 31, 2021

(C) 2021 The Author(s)

\begin{abstract}
Studying in Hungary has become a new trend among Chinese students under the Belt and Road Initiative. The spectacular tripling of the growth of incoming Chinese students has influenced the number of international students in Hungary. In this paper, 26 in-depth narrative interviews with Chinese students in Hungary were conducted and analysed, employing the grounded theory method. This research reveals that beyond considerable uncertainty regarding future plans and career trajectories, three paths are open for Chinese students in Hungary. The largest group intends to return to China after graduation, although they have doubts concerning whether their acquired skills and knowledge can be utilised. The second group aims to find niche jobs, in which they can utilise their in-betweenness. Finally, a small proportion consciously builds their network and aims to remain in Hungary or Europe, engage in further studies or seek employment. The findings contribute to policymakers who support Chinese international educational mobility and to individual Chinese students that wish to widen their horizons and find alternative career paths.
\end{abstract}

\section{KEYWORDS}

Chinese students, Hungary, educational mobility, career trajectories, narrative analysis

JEL CODES

F22, I23, J26

\footnotetext{
*Corresponding author: E-mail: Henriett.primecz@uni-corvinus.hu
} 


\section{INTRODUCTION}

The internationalisation of higher education is an ongoing process and educational excellence can partly be estimated by the proportion of international students. In line with European initiatives, Hungary is engaged in encouraging international students to study in the country. Its specific target is 40,000 international students by 2023 , almost double the 23,000 in 2013 . China views the internationalisation of tertiary education as an opportunity and thus encourages talented students to study abroad, learn new skills, gain experience and develop networks in foreign countries, with the hope that they will return and use their knowledge for the development of their country. International students can be presented as a source of increased soft power, which helps the two countries to build a relationship, and studying in Hungary has become a new trend among Chinese students under the Belt and Road Initiative. In 2019, Chinese students constituted the second largest international student population after Germans in Hungary; China therefore became the largest group of non-European international students in Hungary (Hungarian Central Statistical 2020). The spectacular tripling in incoming Chinese students comprises a large part of foreign national students in Hungary (Li 2020).

The Chinese-Hungarian relationship started to intensify with the launch of the Belt and Road Initiative (BRI) in 2015. Hungary was the first and foremost European country to sign documents with China (Turcsányi et al. 2019). China and Hungary have set an example for friendly cooperation between countries through the " $17+1$ Cooperation" platform, which is established based on the shared will of China and Central and Eastern European Countries (CEEC). As a result of those processes, the Sino-Hungarian relationships have stepped up to the level of a comprehensive strategic partnership based on the developing of friendship and winwin cooperation (Chen - Ugrósdy 2019). In this context, it is important to investigate if the expectations of Chinese students who graduate in Hungary are fulfilled - if, in other words, they actually benefit from a Hungarian education in China or internationally, and if they have a chance to receive high-status jobs after graduation.

International education as a soft power tool intensified bilateral cooperation. As a result, the enhanced structure of scholarships needs to be specified. The most decisive element is the bilateral term launched in 2013, which is held by the Chinese government scholarship and the large-scale Stipendium Hungaricum scholarship programme, managed by the Tempus Public Foundation (TKA) government agency. Stipendium Hungaricum aims to attract international students via the implementation of intergovernmental education agreements for foreign students in Hungary, by covering tuition fees, and even contributing to accommodation and living costs.

After a slow start (47 students in 2013), the number of applicants has grown exponentially, and Stipendium Hungaricum scholarship was awarded to over 3,800 students in 2017/2018 (Stipendium Hungaricum 2019; Li 2020). Among the partner countries, applications from China have increased from 293 in 2015 to 402 in 2019. Figure 1 illustrates this growth. Complemented by tuition fee-paying international students, this means Hungary has become a significant receiver of such students compared to previous decades. Among international students, Chinese students play a vital role, being the second largest community in 2019 (Hungarian Central Statistical Office 2020). Importantly, such a state scholarship programme strengthens sustainable relationships with Chinese students and their role as "cultural ambassadors" after graduation (Tarrósy - Vörös 2019). 


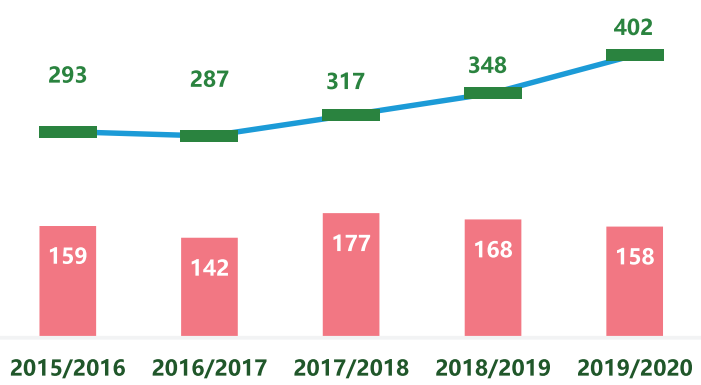

Fig. 1. Number of Chinese applicants and recipients of Stipendium Hungaricum grants (2015-2019) Source: authors, based on Tempus Public Foundation (2019).

Based on a qualitative explorative study with 26 Chinese students in Hungary, this article examines their future plans and career trajectories. The first part of the article outlines the theoretical framework of the investigation, then presents the data collection and analysis. The findings and discussion reveal that the majority of Chinese students in Hungary are uncertain about their future, though three distinct paths could be identified. The largest proportion of investigated students plan to return to China, while several of them are unsure if their newly acquired skills and knowledge can be effectively utilised, especially those who studied in Hungarian. The second group of students seek niche career trajectories which utilise their unique experience of in-betweenness. A small proportion of students plan to stay in Hungary or head to Western Europe to complete further study or gain employment. This article contributes to policymakers' knowledge in establishing plans regarding international students' career paths. It is also useful for the Chinese students in Hungary to clearly consider their future path in this wider context.

\section{THEORETICAL CONSIDERATIONS}

Intercultural education is the result of fast-growing internationalisation and sociocultural adaptation and accumulation. It has received increasing attention and is being addressed from different perspectives (Savicki 2008). Siu (1952) put forward the notion that international students are types of strangers that voluntarily spend a medium length of time (six months to five years) in a foreign country without being assimilated. Furnham (1988) added that such students showed an intention to return, to some extent, to their own culture. It is important to explore international students' future plans and dilemmas, because it has significance to other students in choosing international student mobility.

Researchers illustrated that the decision to go abroad to study is the result of a succession of events and decisions over time (King 2013; Lörz et al. 2016; Salisbury et al. 2009; Wingens et al. 2011) and occur with a future career path in mind. Hung (2010) explains four major perceived attractions of studying abroad: teaching quality; opportunities for cultural encounters; the opportunity to work in the host country after graduation; and better career prospects after returning to the home country. 
Social destinations are a crucial part in the course of life. Looking to the future, social destinations motivate international students in their career trajectories. Mobility programmes show that tertiary education is a critical step in the acquisition of the skills needed in labour markets, while Bourdieu (1986) explains economic capital as an individual's economic resources being directly convertible into money or property rights. Furthermore, Giddens (1998) suggested the future has a personal trajectory: students try to improve themselves and become better persons.

Brooks - Everett (2008) and Bowl (2003) pointed to further education as a means of securing more cultural advantages. An OECD report (2010) highlights the importance of parents' socioeconomic status (SES) and children's educational performance in all OECD countries and concluded the fact that inequalities in tertiary education influence their future occupation and income. Prieto (2015) explained that higher education mobility enhances individuals' employment possibilities, whereas language proficiency expands opportunities to work abroad and engenders European values. Bilecen (2017) identified that mobile students might find themselves in privileged positions in labour markets after their mobility experience, or conversely, they might experience disadvantaged positions because they spent time abroad and lost contact with local professionals. The actual outcome is influenced by several dimensions: labour markets, nation-state regulations, higher education systems in the home country and individual demographic characteristics, namely age, gender, career path and socio-cultural background.

Although Nee (1981) revealed that international students accumulate savings in order to return to their hometown in the future, to invest in land and resume family life, so that they become local notables. However, they face challenges when they graduate. Wolfenden (2017) recognised that providing universal access to quality education means addressing these challenges in order for the young people to be adequately prepared for life and work in an increasingly uncertain world. Hence, the majors with which the students graduate and their desired career paths need to be analysised. In terms of Chinese in Hungary, Borsfay - Nguyen (2019) used a qualitative methodology to detect the future visions of Chinese children and adults living in Hungary; the study focused on the experience trajectories and language acquisitions of Chinese children in secondary schools.

Little is known about either the future considerations and dilemmas of Chinese students in Hungary or how such international experiences impact their future choices. Similarly, the difficulties they face after they graduate remain uncertain. Therefore, this study, based on qualitative narrative interviews analysed using the grounded theory method, provides information about Chinese students' future career trajectories. The study is relevant for policymakers making plans about international student pathways and directions. It also provides insights for present and future Chinese students in Hungary. For a potential student, it is worth considering whether their investments in studying in Hungary will pay off, whereas those currently studying might also choose alternative career paths in light of this study.

\section{METHODOLOGY AND DATA}

Due to the relatively unexplored nature of the study, a qualitative research design was applied with data collection through semi-structured narrative interviews with 26 Chinese students studying in Hungary, using purposive sampling (Horváth - Mitev 2015). Narrative interviews 
gave the interviewees the chance to explain their life story with relative freedom and they could highlight the most important aspects and events (Kval, 1996; Rosile et al. 2013) in connection to their study in Hungary. The interviews covered events and considerations before their arrival in the country, including childhood education; previous higher education (if any); the motivation to move to Hungary to study; the interviewees' experiences; and future plans after completing their studies. This article, however, focuses on the final part of the study: future plans and career trajectories.

The interview data was completed with observation before, during and after the interview (Czarniawska 2014). The observational data was a crucial complementary source of analysis (Gaggiotti et al. 2017), but the main data sources were the recorded interviews. The authors used a research diary containing observations, with added initial impressions and interpretations; facts and interpretations were kept clearly distinct (cf. Horváth - Mitev 2015).

A purposive sampling method was applied in order to reach the most reliable sample of Chinese students studying in Hungary. The sampling procedure aimed to ensure maximum variation among the interviewees (cf. Horváth - Mitev 2015). The first author, being a Chinese doctoral student in Hungary, contacted Chinese students in different universities in Budapest and other university towns in Hungary (Pécs, Debrecen, Miskolc and Szeged), and she asked her contacts to introduce her to Chinese students at the given university. Most of the interviewees were not in personal contact with the interviewer before the data collection, but she could relate to newly connected Chinese students relatively easily. The intention was to reach as many different students as possible to facilitate a diverse selection of study areas, educational level, gender and support status (scholarship, self-financing students). Consequently, the 26 research participants were from the People's Republic of China (PRC) and were international students in Hungary. The sample size and the composition of the sample enables reliable conclusions with the help of a qualitative analysis. The duration of data collection was determined by the saturation of empirical material (Kvale 1996). Sample characteristics of Chinese students are detailed in Tables $1-3$ and Figure 2.

Before starting the interviews, the interviewer provided information about the purpose of the study and data handling procedures; the interviewees also had the chance to ask further questions. Informed consent was given, as was permission to record the interviews. Face-to-face semi-structured narrative interviews were conducted in Mandarin Chinese - the first language of all interviewees and the interviewer. Interviews lasted 60-90 min and were conducted at the end of November 2019; the interviewer visited the interviewees in their homes or they met in a quiet café or in study rooms in dormitories. The narrative followed by interviewees was intended

Table 1. Participants' distributed age

\begin{tabular}{|l|l|l|l|}
\hline & Both & Male & Female \\
\hline Average age (year) & 23.8 & 23.1 & 24.4 \\
\hline Max value (year) & 29 & 29 & 27 \\
\hline Min value (year) & 17 & 21 & 17 \\
\hline
\end{tabular}

Source: authors. 
Table 2. Participants' educational level by gender

\begin{tabular}{|l|c|c|c|c|}
\hline \multirow{2}{*}{ Gender } & \multicolumn{4}{|c|}{ Educational level } \\
\cline { 2 - 5 } & Bachelor & Master & Ph.D & Total \\
\hline Male & 9 & 2 & 2 & 14 \\
\hline Female & 4 & 7 & 2 & 12 \\
\hline Total & 13 & 9 & 4 & 26 \\
\hline
\end{tabular}

Source: authors.

Table 3. Participants' major and place of study

\begin{tabular}{|l|c|c|c|c|}
\hline \multirow{2}{*}{ Study place } & \multicolumn{4}{|c|}{ Major } \\
\cline { 2 - 5 } & Humanity & Science & Medical & Total \\
\hline Budapest area & 5 & 3 & 2 & 10 \\
\hline Non-Budapest & 4 & 6 & 6 & 16 \\
\hline Total & 9 & 9 & 8 & 26 \\
\hline
\end{tabular}

Source: authors.

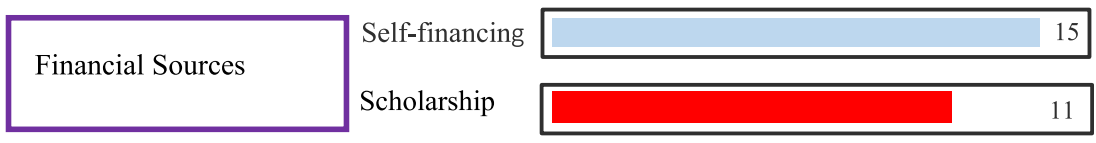

Fig. 2. Participants' financial sources

Source: authors.

to discover their life events and questions followed this course of events. At the beginning of each interview, the interviewer asked about the interviewees' childhood and family.

The grounded theory (GT) method was applied for data analysis following Strauss - Corbin (1998). Interviews, observations and research diary notes were the basis of the data analysis. The first phase open coding of data involved the naming and categorising of phenomena through a close examination of the data. The data was rich and manifold. The open coding process was long and intensive, and several techniques were applied to enhance creativity and comprehensively explore the empirical material (e.g. the Flip-flop technique, systematic comparison, "far-out" comparison and "waving the red flag" technique). This was followed by axial coding with the explicit aim of understanding the data more deeply. This included the investigation of conditions, context, action/interactional strategies and consequences of identifying connections among categories defined by open coding. Subcategories and their relationships to the main categories were discovered. Finally, selective coding was applied, where more abstract 
analysis was conducted and the grounded model from the empirical data was established. The specific data analysis procedures are illustrated in Tables 4 and 5 and Figure 3.

One advantage is that the first author of the article is a native Chinese speaker, so she could conduct the interviews in the interviewees' native language, had insider knowledge of Chinese culture and could empathise with the participants, as she is in a similar situation and has had similar experiences. The second author challenged the first author's taken-for-granted assumptions, questioned her assertions and provided certain insights about Hungarian culture and higher education. The two authors' discussions and debates influenced the findings presented in the following section.

\section{FINDINGS AND DISCUSSION}

Education is the means of social mobility and disadvantaged students aim to increase their social status by investing their time and effort in establishing their life in better socioeconomic conditions. While some studies emphasise the reproduction of class privileges (Bourdieu 1984), others provide evidence on the impact of mobility (DiMaggio 1982; Savage et al. 2013), all the Chinese students interviewed gradually addressed their aspirations and plans after their graduation and evaluated their choice of Hungary in terms of the possible return on their investment including time, money, energy and social connections. Some participants stated they have a transnational future vision after their graduation. Staying in Hungary or a European country was the preferred intention concerning career considerations, whilst returning to China was the preferred intention due to personal and family reasons.

Grounded Theory analysis led to two concepts: "seasoned bridge", meaning a number of Chinese students have mature skills and resources to build a collaboration between the two countries in the specific field, and "dilemma of ambivalent intentions", meaning they are ambivalent about their future; as such, some students choose to stay in Hungary, some students prefer to move to other countries and some consider returning to China.

\subsection{Preparation: "seasoned bridge"}

Social capital is a crucial outcome of tertiary education, for lifelong friendships and collegial liaisons typically develop during university education. Social capital builds on a network of friends, but relocation to China decreases the value of such social capital, as most other students who graduated wanted to remain in Hungary. Some Chinese graduates in Hungary can help build lasting bridges to facilitate the maintenance and development of bilateral ties between China and Hungary; for instance, they were motivated to stay connected with communities they had spent time amongst. Some interviewees had started to prepare to return home. Uncertainty about future plans is typical, and one interviewee explains his rationale for being active in the Chinese community in his university thus:

In the long run, I will go back to China, even though I am not sure of the exact time. But I have been disconnected from friends at home for ten years, and I am a little worried that I will have a reverse culture shock. Therefore, I participated in the Chinese student community and became a leader of the student council [...] so that I could learn from them, which will benefit me when I return to China in several years' time. (Interviewee 16). 
Table 4. Examples of open coding

\begin{tabular}{|c|c|}
\hline Open coding & \\
\hline Prepare to return & $\begin{array}{l}\text { You know my internship is at a Hungarian-Chinese company, which is } \\
\text { near our university. It is a big company in China. Even if the starting } \\
\text { pay is low, I am prepared to tough it out as a learning experience and } \\
\text { to gain experience. Moreover, I can explore more work-related skills } \\
\text { and connections. }\end{array}$ \\
\hline Make a connection & $\begin{array}{c}\text { I have this idea because I feel that the education market in my } \\
\text { hometown is not full, whether it's the IELTS training or services for } \\
\text { going abroad. But the final determination depends on the structure of } \\
\text { market research. }\end{array}$ \\
\hline The reason behind the return & $\begin{array}{l}\text { In terms of a future plan, I have concentrated on my family, home } \\
\text { country and region, and I aspire to become an educational agent. I } \\
\text { think that would be really beneficial for the students in my region, } \\
\text { which is a less developed area. I think that it would be a 'success' to } \\
\text { have good benefits for their future and would probably change their } \\
\text { career and life paths. }\end{array}$ \\
\hline Settle in Hungary & $\begin{array}{c}\text { There are a lot of things that I am familiar with because I have been } \\
\text { here for } 5 \text { years, but if I go back (to China) that means I need to } \\
\text { abandon all my Hungarian networks. I know I need to consider my } \\
\text { career, but at least it is stable here. }\end{array}$ \\
\hline Back to China & $\begin{array}{c}\text { It might be hard for me to work in Hungary or European countries } \\
\text { because of language inadequacies. }\end{array}$ \\
\hline Move to another European country & $\begin{array}{c}\text { In the long run, I would like to continue my doctoral studies in } \\
\text { Western Europe if conditions permit, because all my studies in } \\
\text { Hungary are related to European cases. }\end{array}$ \\
\hline Current dilemma & $\begin{array}{l}\text { In the current situation, I am struggling between accepting my } \\
\text { stereotyped identity in China and embracing another identity in } \\
\text { Hungary. Actually, different outcomes have different advantages and } \\
\text { disadvantages. I will probably be entitled to benefits and a higher } \\
\text { position if I go back to China, but you know, I have to suffer from } \\
\text { constant stress in the competitive atmosphere in China. I want to } \\
\text { escape the stress of expectations if I return home. In the latter case, it } \\
\text { would be difficult for me to find a job in Hungary or Europe. }\end{array}$ \\
\hline Local language barriers & $\begin{array}{c}\text { It might be hard for me to work in Hungary or European countries } \\
\text { because of language inadequacies. }\end{array}$ \\
\hline Future dilemma & $\begin{array}{l}\text { It's troublesome to make a decision after graduation. I would like to } \\
\text { find a job in Hungary and get work experience; however, my parents } \\
\text { want me to apply to a state-owned enterprise, which puts me in an } \\
\text { embarrassing situation. In fact, we all think very well, but who knows } \\
\text { what will happen in the future, or you may completely change your } \\
\text { direction and situation because of certain things. }\end{array}$ \\
\hline
\end{tabular}


Table 4. Continued

\begin{tabular}{|l|c|}
\hline Open coding & \\
\hline No guarantee of good employment & $\begin{array}{c}\text { If I go back home, people in China might question my knowledge and } \\
\text { my actual abilities in professional practice. The perception of } \\
\text { overseas study is likely misrecognised by both myself and other } \\
\text { people. I mean, they are not qualified to judge me because they } \\
\text { haven't gone abroad. I cannot bear it because this is people's } \\
\text { stereotype of students studying abroad. }\end{array}$ \\
\hline
\end{tabular}

Source: authors.

Table 5. Axial coding

\begin{tabular}{|l|c|}
\hline Axial coding & Prepare to return \\
\hline Return Intention & Make a connection \\
\cline { 2 - 2 } & The reason behind the return \\
\cline { 2 - 2 } & Settle in Hungary \\
\hline Choices & Back to China \\
\cline { 2 - 2 } & Move to another European country \\
\cline { 2 - 2 } & Current dilemma \\
\hline \multirow{3}{*}{ Dilemmas } & Local language barriers \\
\cline { 2 - 2 } & Future dilemma \\
\cline { 2 - 2 } & No guarantee of good employment \\
\cline { 2 - 2 } & \\
\cline { 2 - 2 } &
\end{tabular}

Source: authors.

Another interviewee consciously chose a career which links his experience in Hungary and his future Chinese residence: he plans to be a teacher of international Chinese education after he completes his postgraduate study in Europe. Since the Confucius Institute has spread all over the world, he also wants to be a person who can contribute to his home country under the BRI. Consequently, he has long since been a participant in the university's Confucius Institute. "Seasoned bridge" means making contributions to two countries. Experiencing a foreign work environment is beneficial upon their return; they hope to use the European working experience as a springboard to obtain a good job as they return to China. In the long term, however, they are eager to return to China, even if they have offers to stay abroad. One interviewee knows a friend who benefitted from BRI, and he would take advantage of more opportunities in the future if offered. Another possibility is working for Hungarian-Chinese companies, where both experience and knowledge would count: 

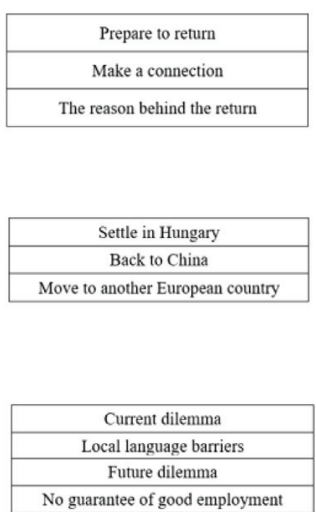

ocal language barriers

Future dilemma

No guarantee of good employment

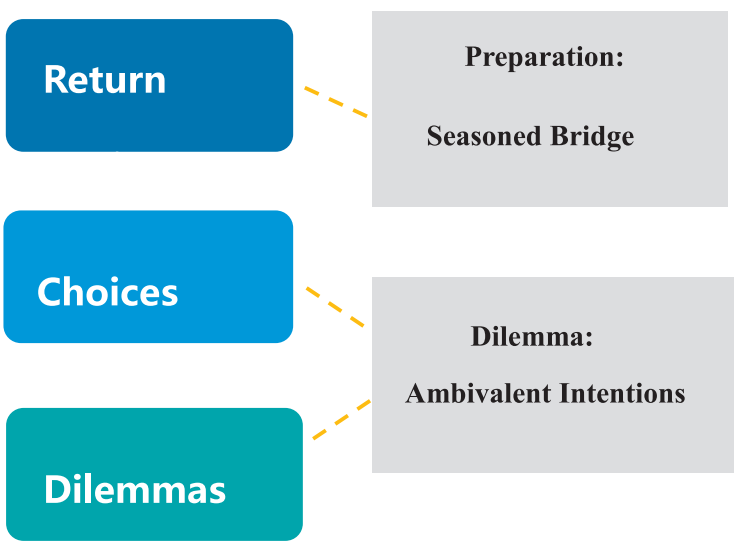

Fig. 3. Selective coding

Source: authors.

You know, my internship is at a Hungarian-Chinese company, which is near our university. It is a big company in China. Even if the starting pay is low, I am prepared to tough it out as a learning experience and to gain experience. Moreover, I can explore more work-related skills and connections. (Interviewee 10)

Other interviewees were prepared to stay in Hungary and consciously planned and organised their careers to settle in Europe, e.g. one interviewee has spent ten years in Hungarian tertiary education and wants to be a dentist in a hospital, following the advice given by Hungarian professors who come to China for short-term lecturing and research. He followed his guidance and arrangements at university so that he had a good relationship with many professional dentists and peers in Hungary. Another interviewee, who is a veterinarian, followed the same pattern.

Additionally, one interviewee made a conscious decision to move to Europe from China taking into consideration the education market of the two places, and it was advantageous to return. She keeps her possibilities open based on the information she gathers on the two markets.

I have this idea because I feel that the education market in my hometown is not full, whether it's the IELTS training or services for going abroad. But the final determination depends on market research. (Interviewee 2)

\subsection{Dilemma: ambivalent intentions}

While some of the students seemed to be decisive about their future trajectories, most of them were indecisive, and they identified advantages and disadvantages for staying and returning; their plans fluctuated as a result. There were three options regarding their immediate future direction: staying in Hungary, moving to another European country or returning home to China. 
Those interviewees who had already spent considerable time in Hungary tended to choose to stay and secure a job. Their reasoning emphasised their recent experiences and most importantly essential networks connected to work and friendship. Stability paid a role when arguments were set.

There are a lot of things that I am familiar with because I have been here for 5 years, but, if I go back (to China), that means I need to abandon all my Hungarian networks. I know I need to consider my career, but at least it is stable here. (Interviewee 26)

Those students who spoke Hungarian were in a special situation. The interviewed Hungarian-speaking students were inclined to stay in Hungary because of language advantages. They would take advantage of further Hungarian studies step-by-step so that they could be a professional Hungarian speaker. Some of them chose to continue their studies to master the language and improve their Hungarian networks. A second option for students was to move to another European country to pursue their future careers.

Six interviewees preferred to take advantage of the 9-month period to find job opportunities in Hungary or Europe, since Chinese citizens cannot move freely in Europe without visas. For those with good academic results, their potential destination would be Germany and Northern Europe after strategically comparing the job markets in their professions. In this sense, a Hungarian education is a logical stepping stone that provides them with more career opportunities, social resources and work experience. One interviewee wanted to pursue his career or studies in Germany, while another also considered German opportunities:

I want to go to Germany after graduation. I am looking forward to the strict academic environment and good opportunities there. (Interviewee 12)

Another interviewee's trajectory was to continue to post-doctoral research in other European countries, such as Switzerland or Germany, since she had developed well-connected relationships in Hungary. Beyond this, several interviewees also stated that their dream was to go to Western Europe after graduation.

In the long run, I would like to continue my doctoral studies in Western Europe if conditions permit, because all my studies in Hungary are related to European cases. (Interviewee 22)

The final option is return to China, which was apparently the most favourable option for the participants. The Chinese students interviewed initially had a vague view when they first arrived in Hungary. As they approached graduation, their return intentions were based on family concerns and few job opportunities in Europe; this motivated their return to China. Most of them indicated that they visited China frequently each year. Twelve interviewees stated their fears about "fitting into" the Hungarian or European job markets as their primary concern. Consequently, their return plans became geographically flexible based on their job location preferences. Eight interviewees considered an exact city as a better place to develop their careers in the long term. It is noteworthy to mention that this differs from Goldsmith and Beegle (1962) point of view that students' return migration behaviours rely on external factors related to social and political issues instead of their involuntary return plans. In contrast, the desire of Chinese students in Hungary to return to China was rarely associated with external factors but instead with internal expectations. One interviewee demonstrated her aspiration to return to China after 
graduation by explaining the difficulties she might have faced in Hungary or in Europe due to the language barriers.

It might be hard for me to work in Hungary or European countries because of language inadequacies. (Interviewee 5)

The main topics appearing in the return decision were related to family ties. Close family ties are one of the top reasons for Chinese students choosing to return. Filial piety is embodied in the Chinese cultural family responsibility (Ong 1999). Ong concluded that "[...] the male vision of the Chinese society [...t] races family genealogies from fathers to sons, who are constructed as male-to-male partners [...]" (Ong 1999: 151). Most of the students regarded family concerns as the most important factor and see a return to their homeland as a much-needed respite, since most participants were from single-child families.

This results in a series of demographic issues that involve living with or being close to their families and providing care, which is part of their Chinese cultural background. This finding concurs with Brooks and Waters' argument that family ties are an essential component impacting Chinese students. One interviewee focused on family when she explained her future plans, adding that she wants to give back what she can to her country and, more specifically, her region:

In terms of a future plan, I have concentrated on my family, home country and region, and I aspire to become an educational agent. I think that would be really beneficial for the students in my region, which is a less developed area. I think that it would be a 'success' to have good benefits for their future and would probably change their career and life paths. (Interviewee 2)

The students experience slightly different gender expectations on their return. Male Chinese students who were interviewed mentioned that they needed to be the mainstay of their families and that they would eventually be required to bear the burden of the whole family. Most of them acknowledged that they would choose for their parents to come to a European country, stay in Europe temporarily and then go back to China after acquiring work experience. Lin and Ghaill (2017) further concluded that men assume responsibility for the family more than women in patriarchal Chinese society. Most female participants said they would return and support their parents as they get older.

The reality is not quite as smooth as these three options. Yoshikawa's Double-Swing Model was put forward in 1988, for which there are five stages: contact, disintegration, reintegration, autonomy and double-swing. This model provided a third view which transcended the binary opposites of East and West in a state of dynamic in-betweenness.

Some interviewed Chinese students acknowledged that they are in an in-between position and have many considerations. Sometimes, the in-between status made interviewees feel excluded. To be specific, they desired to embrace the cultural logic of capitalist accumulation in Europe while having filial and nostalgic feelings to return home during their transnational social experiences. For the non-Hungarian speakers, their dilemma was concentrated on their choice of future. One interviewee vacillated between his preferred choice, a job in Hungary and his parents' preference, a state-owned enterprise career in China:

It's troublesome to make a decision after graduation. I would like to find a job in Hungary and get work experience; however, my parents want me to apply for a state-owned enterprise, which puts me in an embarrassing situation. In fact, we all think very well, but who knows what will happen in the 
future, or you may completely change your direction and situation because of certain things. (Interviewee 14)

Another interviewee explained that life is more stressful in China, and he would prefer to stay in Hungary, where life is more relaxed:

In the current situation, I am struggling between accepting my stereotyped identity in China and embracing another identity in Hungary. Actually, different outcomes have different advantages and disadvantages. I will probably be entitled to benefits and a higher position if I go back to China, but you know, I have to suffer from constant stress in the competitive atmosphere in China. I want to escape the stress of expectation if I return home. In the latter case, it would be difficult for me to find a job in Hungary or Europe. (Interviewee 19)

Another interviewee, who had a Hungarian-speaking internship and had adapted to the local culture - an advantage of staying in Hungary - faced the same dilemma. But he still did not decide on a country for a long time. Generally, the difficulties for the Hungarian-speaking students might be more challenging than for the English-speaking ones. One interviewee elaborated upon the same dilemma; he would not use the rarely spoken language in countries other than Hungary:

In fact, if I were to go back to my country, I might rarely use Hungarian in the future. (Interviewee 25)

In the choice between returning to China and staying overseas, one interviewee was also facing tremendous stress when he found that he had no choice but to go home after three years of studying in Hungary. He expressed his concern about losing track of what was happening in China, but staying in Hungary would result in abandonment in his personal life:

In fact, I have given up a lot of opportunities in my home country. If I had been studying at the previous university, my study track would have been different than here. I have no choice but to go back home; the opportunity to study in Hungary was tantamount to changing my life direction. (Interviewee 12)

There is a growing population of highly skilled returnees from the West to China with advanced degrees. In fact, Chinese international students seem to understand this situation and acknowledge that their foreign degrees no longer uniformly represent high-quality education. However, there is no doubt from the employers on the "authenticity" of returnees' foreign experience. Regardless, some of the interviewees perceived their own niches in job markets under different cultural contexts. Two interviewees explained that foreign degrees are not a guarantee of good employment.

If I go back home, people in China might question my knowledge, which is beyond my actual abilities in professional practice. The perception of overseas study is likely misrecognised by both myself and other people. I mean, they are not qualified to judge me because they haven't gone abroad. I cannot bear it because this is people's stereotype of students studying abroad. (Interviewee 3)

In fact, I think that the abilities of the returnees are not necessarily strong. (Interviewee 9)

Eventually, in terms of future careers, the participants expressed their concerns as to the risks of being absent from China during their period of study in Hungary. This worry was linked to 
the possibility of missing networking with people in China. In fact, Chinese culture is characterised by deep-rooted social ties and connections. One interviewee elaborated his hesitation by explaining his perceived lack of skills, which is necessary in China for career progression.

I do know that communication skills are the most important skill for my career path, but you know, I stayed in Hungary for ten years, and sometimes complicated interpersonal relations scared me. The solution for me to overcome this dilemma was to join in the Chinese student community and to be a representative at [a non-Budapest] university, so that I could learn soft skills and equip myself with social competence. (Interviewee 16)

Moreover, the students' return is essentially a one-way movement, which means that once they accepted employment back in China, they would no longer able to work in Hungary or Europe.

\section{CONCLUSIONS}

The research findings identify that Chinese students face a dilemma when they decide about their future. It seems there is no logical continuation of studies in Hungary for Chinese students. From a theoretical perspective, this research contributes to existing theories about the career prospects of international students, particularly for future considerations of cultural mobility. The research contributes a set of suggestions for further reflection aimed at Hungarian decisionmakers concerning cultural diplomacy, and is also useful for Chinese students in Hungary who will be able to consider their future opportunities in a wider context, though this research was conducted during these studies, so their perceptions of future trajectories might be distorted.

Keeping in mind the limitations of the research, future directions open up. A significant limitation is that the research is an exploratory qualitative study and builds on only 26 Chinese students studying in Hungary. Consequently, the results are not generalisable. This limitation can be overcome with a distinct research study building on a larger and representative sample. We propose this as a future direction of investigation concerning Chinese students in Hungary. Another possibility for future research is follow-up studies after students' re-entry into China; these could be useful to supplement this research and provide empirical evidence for the transformative nature of Chinese students in Hungary. Another possible direction would be to have comparative studies about Chinese students pursuing an education in Hungary in comparison with other Central Eastern-European countries, such as those in Poland or the Czech Republic. It would be even more exciting to have a longitudinal study of career outcomes for those who completed their tertiary studies in Hungary (or Central Eastern-Europe) as compared to the English-speaking world. This study would, of course, provide evidence for the return on investment in foreign studies for Chinese students.

Funding information: Funding provided by Corvinus University of Budapest (BCE). The present publication is the outcome of the project "From Talent to Young Researcher project aimed at activities supporting the research career model in higher education," identifier EFOP-3.6.3VEKOP-16-2017-00007 co-supported by the European Union, Hungary, and the European Social Fund. 


\section{ACKNOWLEDGEMENTS}

Li Xueyan would like to thank the China Scholarship Council and the Stipendium Hungaricum Scholarship for providing an opportunity to study at Corvinus University. She would not have completed this article without the contribution of many people. Her deep and sincere gratitude goes to all her lecturers, including Prof. György Lengyel, Tamás Bartus, Beáta Nagy, and Keszey Tamara Nóra, who had the patience to help her in editing and this manuscript. Finally, she extends her gratitude to her colleagues, the reviewers and the editors at the journal for constructive comments and suggestions.

\section{REFERENCES}

Bilecen, B. - Van Mol, C. (2017): Introduction: International Academic Mobility and Inequalities. Journal of Ethnic and Migration Studies 43(8): 1241-1255. https://doi.org/10.1080/1369183 X.2017.1300225.

Bourdieu, P. (1984): Distinction: A Social Critique of the Judgement of Taste. London: Routledge.

Bourdieu, P. (1986): The Forms of Capital. In: Richardson, J. (ed.): Handbook of Theory and Research for the Sociology of Education. Westport, CT: Greenwood, pp. 241-258.

Bowl, M. (2003): Non-Traditional Entrants to Higher Education: "They Talk about People Like Me". London: Trentham Books.

Borsfay, K. - Nguyen, L. L. A. (2019): Future Visions: Narratives of Chinese Children and Adults Living in Hungary. In: Chen, X. - Ugrósdy, M. (eds): A 70-year Overview in Light of Bilateral Diplomatic Dynamics. Budapest: China-CEE Institute.

Brooks, R. - Everett, G. (2008): The Impact of Higher Education on Lifelong Learning. International Journal of Lifelong Education 27(3): 239-254. https://doi.org/10.1080/02601370802047759.

Chen, X. - Ugrósdy, M. eds (2019): A 70-year Overview in Light of Bilateral Diplomatic Dynamics. Budapest: China-CEE Institute.

Czarniawska, B. (2014): Social Science Research: From the Field to the Desk. London: SAGE Publication.

DiMaggio, P. (1982): Cultural Capital and School Success: The Impact of Status Culture Participation on the Grades of U.S. High School Students. American Sociological Review 47(2): 189-201. https://doi.org/ $10.2307 / 2094962$.

Furnham, A. (1988): The Adjustment of Sojourners. In: Kim Y. Y. - Gudykunst W. B. (eds): Cross-cultural Adaptation: Current Approaches. California, pp. 42-61.

Gaggiotti, H. - Kostera, M. - Krzyworzeka, P. (2017): More than a Method? Organisational Ethnography as a Way of Imagining the Social. Culture and Organization 23(5): 325-340. https://doi.org/10.1080/ 14759551.2016.1203312.

Giddens, A. (1998): Risk Society: the Context of British politics. In: Franklin, J. (ed.): The Politics of Risk Society. Cambridge: Polity.

Goldsmith, H. C. - Beegle, J. A. (1962): In: The Initial Phase of Voluntary Migration. Michigan State University, Rural Sociology Studies, East Lansing.

Horváth, D. - Mitev, A. (2015): Alternatív kvalitativ kutatási kézikönyv [Handbook of Alternative Qualitative Research]. Budapest: Alinea.

Hung, F. (2010): Intention of Students in Less Developed Cities in China to Opt for Undergraduate Education Abroad: Does This Vary as Their Perceptions of the Attractions of Overseas Study Change? 
International Journal of Educational Development 30(2): 213-223. https://doi.org/10.1016/j.ijedudev. 2009.03.003.

Hungarian Central Statistical Office. (2020): https://www.ksh.hu.

King, R. - Raghuram, P. - Carlson, S. (2013): Becoming a Mobile Student - a Processual Perspective on German Degree Student Mobility. Population 19(2): 168-180. https://doi.org/10.1002/psp.1749.

Kvale, S. (1996): InterViews. An Introduction to Qualitative Research Writing. Thousand Oaks, CA: Sage. Li, X. (2020): Chinese Students Choosing Hungarian Tertiary Education: A Systematic Review. East Asia 37: 317-330. https://doi.org/0.1007/s12140-020-09333-y.

Lin, X. - Ghaill, M. (2017): Shifting Discourses from Boy Preference to Boy Crisis: Educating Boys and Nation Building in Neoliberal China. Discourse: Studies in the Cultural Politics of Education. https://doi. org/10.1080/01596306.2017.1312284.

Lörz, M. - Netz, N. - Quast, H. (2016): Why Do Students from Underprivileged families Less Often Intend to Study Abroad? Higher Education 72(2): 153-174. https://doi.org/10.1007/s10734-015-9943-1.

Nee, V. - Nee, B. (1981): Longtime Californ': A Documentary Study of an American Chinatown. New York: Pantheon Books.

OECD (2010): A Family Affair: Intergenerational Social Mobility across OECD Countries. In: OECD: Economic Policy Reforms 2010. Paris: OECD, pp. 181-198. https://doi.org/10.1787/growth-2010-38-en.

Ong, A. (1999): In: Flexible Citizenship: The Cultural Logics of Transnationality. Duke University Press, Durham.

Prieto, P. (2015): Intonational Meaning. Wires Cognitive Science 6(4): 371-381. https://doi.org/10.1002/wcs. 1352.

Rosile, G. A. - Boje, D. M. - Carlon, D. M. - Downs, A. - Saylors, R. (2013): Storytelling Diamond: An Antenarrative Integration of the Six Facets of Storytelling in Organization Research Design. Organizational Research Methods 16(4): 557-580.

Salisbury, M. H. - Umbach, P. D. - Paulsen, M. B. - Pascarella, E. T. (2009): Going Global: Understanding the Choice Process of the Intent to Study Abroad. Research in Higher Education 50(2): 119-143. https:// doi.org/10.1007/s11162-008-9111-x.

Savage, M. - Devine, F. - Cunningham, N. - Taylor, M. - Li, Y. - Hjellbrekke, J. - Le Roux, B. - Friedman, S. - Miles, A. (2013): A New Model of Social Class? Findings from the BBC's Great British Class Survey Experiment. Sociology 47(2): 219-250. https://doi.org/10.1177/0038038513481128.

Savicki, V. (2008): In: Developing Intercultural Competence and Transformation: Theory, Practice and Application in Intercultural Education Sterling. Stylus, Virginia.

Siu, P. C. P. (1952): The Sojourner. American Journal of Sociology 58(1): 3444.

Stipendium Hungaricum Scholarship Program (2019): Call for Application (2019). http://www. stipendiumhungaricum.hu/, accessed 18/19/2019.

Strauss, A. - Corbin, J. M. (1998): Basics of Qualitative Research: Techniques and Procedures for Developing Grounded Theory (2 ${ }^{\text {nd }}$ Edition). Thousand Oaks, California: Sage.

Tarrósy, I. - Vörös, Z. (2019): Sino-Hungarian Cooperation in Higher Education and Research. In: Chen, X. - Ugrósdy M. (eds): A 70-year Overview in Light of Bilateral Diplomatic Dynamics. Budapest: ChinaCEE Institute.

Turcsányi, R. - Karásková, I. - Matura, T. - Šimalčík, M. (2019): Followers, Challengers, or By-Standers? Central European Media Responses to Intensification of Relations with China. Intersections. East European Journal of Society and Politics 5(3): 49-67. https://doi.org/10.17356/ieejsp.v5i3.564.

Wingens, M. - de Valk, H. - Windzio, M. - Aybek, C. (2011): The Sociological Life Course Approach and Research on Migration and Integration. In: Wingens, M. - Windzio, H. - de Valk, H. - Aybek, C. (eds): 
A Life-Course Perspective on Migration and Integration. Cham: Springer, pp. 1-26. https://doi.org/10. 1007/978-94-007-1545-5_1.

Wolfenden, F. - Buckler, A. - Santos, C. - Mittelmeier, J. (2017): Education Workforce Initiative: Initial

Research. http://educationcommission.org/wp-content/uploads/2018/08/Education-Workforce-

Initiative-Initial-Literature-Review.pdf, accessed 05/07/2021.

Open Access. This is an open-access article distributed under the terms of the Creative Commons Attribution 4.0 International License (https://creativecommons.org/licenses/by/4.0/), which permits unrestricted use, distribution, and reproduction in any medium, provided the original author and source are credited, a link to the CC License is provided, and changes - if any - are indicated. (SID_1) 